\title{
Effect of frequency of Rhopalurus junceus scorpion venom collection on protein content and biological activity
}

\author{
Alexis Díaz-García ${ }^{*}$, Arianna Yglesias-Rivera², Jenny L Ruiz-Fuentes ${ }^{3}$, Rayner Ochoa-Cardentey², Jose Raúl Torres Viltres ${ }^{2}$, Hermis \\ Rodríguez-Sánchez ${ }^{3}$ and Tania Gómez Peña ${ }^{4}$ \\ ${ }^{1}$ Millennium Nucleus of Ion Channels-Associated Diseases (MiNICAD), Postdoctoral Fellowship, Chile University, Santiago, Chile \\ ${ }^{2}$ Research Department, Laboratories of Biopharmaceuticals and Chemicals Productions (LABIOFAM), Havana, Cuba \\ ${ }^{3}$ Microbiology Department, Tropical Medicine Institute "Pedro Kouri”, Havana, Cuba \\ ${ }^{4}$ Quality control Department, Center of Molecular Immunology, Havana, Cuba
}

\begin{abstract}
Frequency of scorpion venom extraction could influence the quality of venom and as a result may vary their biological activity, whether pharmacological or toxicological behavior, due to venom regeneration is an asynchronous process. In the present study we evaluate the protein content, concentration and biological activity of Rhopalurus junceus scorpion varying the extended periods of venom collection. Three scorpion groups were re-milked at 7, 15 and 21 days after first extraction. Differences in protein content were analyzed by SDS- PAGE and HPLC techniques. The biological effect against A549, C6/36HT and Vero cells was assayed by MTT using different venom concentration $(0.062 ; 0.125 ; 0.25 ; 0.5 ; 1 \mathrm{mg} / \mathrm{mL})$. Venom from day 7 and 15 showed significant differences in protein concentration $(p<0.05)$ respect to first extraction. SDS-PAGE and HPLC showed the highest and lowest variation in venom content, at day 7 and 21 respectively. Vero normal cells viability was not affected at all extraction periods. Meanwhile, insect cells, C6/36HT was sensitive at all extraction periods. Extended periods of venom collection was positively correlated with the regeneration of venom composition and the increase of cytotoxic effect against A549 cancer cells. $R$. junceus venom regeneration showed to be asynchronous depending of the target cell. Besides, venom seems to be completely renewal after 21 days showing high protein content and reproducible results against cancer cells respect to former extraction.
\end{abstract}

\section{Introduction}

Most of the scorpion venoms used in pharmacological investigation or to obtain antivenom serum usually represents a mix of proteins and peptides. This pooled venom usually comes from the extraction of individual specimen keep under laboratory conditions [1]. Venom composition can be influenced by different factors like geographical location, age, diet, sex, extraction process, time intervals for extraction, and others [2]. Among these different factors, the selection of the appropriated time intervals for extraction influence positively for obtaining the full venom composition, representing a critical step for it $[3,4]$. Study of this factor for procurement similar protein content between each extraction could guarantee reproducible biological activity for venom used in biomedical research or antivenom production.

Rhopalurus junceus scorpion (R. junceus) is Cuban endemic specie that has been used in traditional medicine for treatment of some illness including cancer. The scorpion is widespread and its venom is not considered dangerous to human health. Previous reports from our group have shown that scorpions kept under similar conditions as laboratory animals can be milked to obtain venom with selective cytotoxic and apoptotic effect against cancer cells without affecting the normal ones $[5,6]$. However, the reproducibility of the experiments is required for pharmacological and toxicological experiments and should be done base on venom obtained under standard conditions. Extraction period should be studied to identify the condition of obtaining scorpion venom for granting reproducible results and reduce the scorpion stress as laboratory animal. Considering these previous features in the present study, we evaluated the effect of frequency of venom collection on protein content and biological activities in vitro. Here we demonstrated that different extraction periods provoke variation in protein content and biological activity of $R$. junceus venom.

\section{Methods}

\section{Reagents}

Dulbecco's modified Eagle's medium was purchased from GIBCO/ BRL (Gaithersburg, MD). Fetal bovine serum (FBS) was purchased from Hyclone. The 3-[4.5-dimethylth-iazol-2-yl]-2,5-diphenyl tetrazoliumbromide (MTT) reagent was purchased from Sigma. All other chemicals and reagents were obtained from Sigma (St. Louis, $\mathrm{MO})$.

\section{Venom source}

Adult Rhopalurus junceus scorpions, collected in Cienfuegos province, were kept in captivity for at least 1 month before venom extraction. Recent experiments demonstrated that lesser time of venom

*Correspondence to: Alexis Díaz-García, Millennium Nucleus of Ion ChannelsAssociated Diseases (MiNICAD), University of Chile, Faculty of Medicine, North Campus, Ave. Independencia 1027 Hall B, First Floor, Chile, E-mail: alexisdg76@gmail.com

Key words: cancer cells, cytotoxicity, extraction period, Rhopalurus junceus scorpion, venom regeneration

Received: October 28, 2019; Accepted: December 11, 2019; Published: December 13, 2019 
collection influence the venom composition and biological activity (unpublished results). Scorpions were maintained under Bioterium conditions, in individual plastic cages at $22.8^{\circ} \mathrm{C}$ and $76 \%$ relative humidity in laboratories belonging to The Entrepreneurial Group of Biopharmaceuticals and Chemical Productions (LABIOFAM). Water was given ad libitum using a cotton disc and animals were fed once a week. Venom from scorpions was obtained by electrical stimulation. This method has been recognized to cause fewer traumas, do not damage animal integrity and permits the obtaining best yields compared to other methods [7-9]. The obtaining, bioterium condition, management of scorpion colonies, and collection of venom have been approved by the Ministry of Science, Technology and Environment of Cuba (CITMA 20/2016). Three groups of scorpion containing 50 animals each were used. First group (G1) was milked on day 1 and 7 days after first extraction. Second group (G2) was milked on day 1 and 15 days after first extraction. Third group (G3) was milked on day 1 and 21 days after first extraction. Venom from each group at each extraction period were obtained separately and used for protein concentration, SDS-PAGE, HPLC and biological activity.

\section{Determination of protein concentration}

Venom was obtained dissolved in distilled water in the same volume for each groups and centrifuged at $10000 \mathrm{xg}$ for $15 \mathrm{~min}$. The supernatant was filtered by using a $0.2 \mu \mathrm{m}$ syringe filter and stored at $-20^{\circ} \mathrm{C}$ until used. The protein concentration was calculated by method of Lowry modified [10].

\section{Gel electrophoresis of venoms}

Electrophoretic analysis of each pooled venom was carried out according to previous method [11] with $4 \%$ stacking gel and $16 \%$ separating gel under non-reduced and reduced (2-mercaptoethanol, $95^{\circ} \mathrm{C}, 10 \mathrm{~min}$ ) conditions using an electrophoresis chamber (Biorad, Mini-PROTEAN $\left.{ }^{\mathrm{R}} 1 \mathrm{ll}\right)$. All samples were dissolved in a sample buffer (50 mM Tris-HCl, pH 6.8, 0.1 M DTT, 10\% glycerol, 2\% SDS, and $0.1 \%$ bromophenol blue). In each well $50 \mu \mathrm{g}$ of venom was applied and a protein molecular weight marker was used. The run conditions were $300 \mathrm{~V}, 30 \mathrm{~mA}$ as a constant current for two hours. The gels were stained with coomassie brilliant blue G-250 and were subsequently destained with methanol:acetic acid:water (45:10:45).

\section{Chromatographic analysis by reversed phase high performance liquid chromatography (RP-HPLC)}

The soluble venom from each group was set separately on the autosampler and applied to chromatography. Two hundred micrograms were injected and venom was separated by RP-HPLC using a C18 reverse-phase column (Mediterranea Sea $5 \mu \mathrm{m}$ 25x0.46, Teknokroma). The run condition included a linear gradient from $0 \%$ solvent $\mathrm{A}[0.1 \%$ trifluoroacetic acid (TFA) in water] to $60 \%$ solvent B $(0.10 \%$ TFA in acetonitrile) during $60 \mathrm{~min}$ and rate flow of $1 \mathrm{ml} / \mathrm{min}$ and the absorbance was $230 \mathrm{~nm}$. Scorpion venom with a known chromatographic and biological activity profile was used as control sample [6].

\section{In vitro cell viability assay (MTT assay)}

The effect of scorpion venom from the different extraction periods on C6/36HT (CVCL_VH42), monkey kidney normal cell line Vero $\left(\right.$ ATCC $^{\circledast}$ CCL-81 $1^{\mathrm{su}}$ ) and lung carcinoma cell line A549 (ATCC CCL$\left.185^{\mathrm{nx}}\right)$ viability was determined by the MTT assay [12]. The experiments with cell lines were carried out as previously was reported [5]. Briefly, cells were plated in $50 \mu \mathrm{l}$ of medium/well in 96-well culture plates (Costar Corning, Rochester, NY) at $1 \times 10^{4} /$ well and incubated overnight to recovery and cell adhesion in a humidified atmosphere of $5 \% \mathrm{CO}_{2}$ at $37^{\circ} \mathrm{C}$. Fifty microliters of venom were added at final concentration of $0.0620 .12,0.25,0.5$ and $1 \mathrm{mg} / \mathrm{mL}$ in triplicate. Cells with culture medium and without scorpion venom were used as untreated growth control. After treatment for $72 \mathrm{~h}, 10 \mu \mathrm{L}$ of $5 \mathrm{mg} / \mathrm{mL}$ MTT sterile ( $\mathrm{pH}$ 4.7) was added and after $3 \mathrm{~h}$ of incubation, $150 \mu \mathrm{l}$ DMSO was added. Plates were shaken and the absorbance was measured at $560 \mathrm{~nm}$. Absorbance from untreated cells was considered as $100 \%$ of growth and used for viability calculation. The effect of scorpion venom on cell viability was expressed as the $\%$ viability, using the formula: $\%$ viability $=\mathrm{A}_{560}$ of treated cells $/ \mathrm{A}_{560}$ of control cells $\times 100 \%$. The $\mathrm{IC}_{50}$ values (venom concentration that causes $50 \%$ reduction of cell viability) were determined. The experiments were performed three times.

\section{Statistical analysis}

The protein concentration in the first and second venom extraction in each group was compared by using unpaired t-test. The $\mathrm{IC}_{50}$ values were determined by interpolation of tendency line from linear regression curve and they were compared using unpaired t-test. For all analysis we used the GraphPad Prism version 5.03 for Windows, (GraphPad Software, San Diego California, USA). Significant differences were considered for $\mathrm{p}<0.05$.

\section{Results}

Protein concentration from the first and second extraction in each group is shown in the Table 1 . The G1 group showed differences statistically significant $(\mathrm{p}<0.001)$ between the first extraction and after 7 days of former extraction. Similar to G1, in the G2 group there were differences statistically significant between first and second venom extraction $(\mathrm{p}<0.01)$. In this venom obtained after 15 days of previous extraction, protein content showed a non-significant increase respect to second extraction of G1 group. On other hands, in the third group, first and second extractions (after 21 days) were very similar in protein concentration (Table 1).

The electrophoretic analysis of protein content from the different extraction periods under non-reduced and reduced condition are showed in the Figure 1.

Venom from the three groups in the first extraction, under nonreduced conditions, showed similar pattern in the electrophoretic profile with multiple intense proteins bands under $62 \mathrm{kDa}, 42 \mathrm{kDa}, 29$ $\mathrm{kDa}, 22 \mathrm{kDa}, 14 \mathrm{kDa}$ and $10.5 \mathrm{kDa}$ (Figure 1A). A negligible band was observed in the three venom group between $70-95 \mathrm{kDa}$. The second extraction in G1 group showed a similar protein bands pattern but intensity was lesser. In this group, protein bands under $29 \mathrm{kDa}, 22 \mathrm{kDa}$ and $10.5 \mathrm{kDa}$ were less intense and diffused in both, reduced and nonreduced protein electrophoresis (Figure 1). In the second extraction, G2 and G3 groups showed a similar electrophoretic profile respect to previous extractions (Figure 1). Only a slight increase of protein band intensity was observed between $70-95 \mathrm{kDa}$, in second extraction from

Table 1. Concentration values obtained from first and second extraction of scorpions groups. Values represent means \pm SD from two extractions. G1: Scorpions milked on day 1 and 7 days after first extraction. G2: Scorpions milked on day 1 and 15 days after first extraction. G3: Scorpions milked on day 1 and 21 days after first extraction. Asterisk ( $\left.{ }^{*}\right)$ indicates significant differences between first and second extractions $\left({ }^{* * * *} p<0.001\right)$

\begin{tabular}{|c|c|c|}
\hline & \multicolumn{3}{|c|}{ Concentration $(\mathbf{m g} / \mathbf{m L})$} \\
\hline Experimental groups & First extraction & Second extraction \\
\hline G1 & $7.35 \pm 0.33$ & $2.53 \pm 0.42^{* * *}$ \\
\hline G2 & $6.76 \pm 0.63$ & $4.18 \pm 0.23^{* *}$ \\
\hline G3 & $6.12 \pm 0.87$ & $6.66 \pm 0.49$ \\
\hline
\end{tabular}


all three groups, respect to former extractions (Figure 1A, black arrow). Comparison of venom in reduced respect to non-reduced condition showed the presence of new protein bands over $29 \mathrm{kDa}$ and $14 \mathrm{kDa}$ (Figure 1B, black arrows). At the same time, some protein bands under $10.5 \mathrm{kDa}$ disappeared in all samples, under reduced condition, instead, was observed a compact prominent band, suggesting the presence of abundant disulfide-bridge proteins at different levels, in the samples.

Pools of $R$. junceus venom kept under Bioterium conditions were obtained at different extraction periods of 7, 15, 21 days after first extraction. The elution profile of their components in C-18 reverse phase HPLC is shown in Figure 2. The chromatographic profiles from
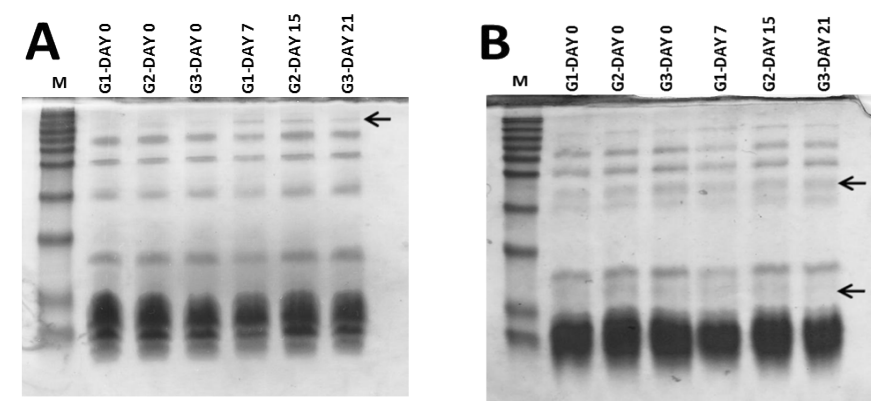

Figure 1. Polyacrilamide gel electrophoresis of scorpion venom protein content from G1, G2, G3 groups. (A) Non-reduced SDS-PAGE. (B) reduced SDS-PAGE. G1: Scorpions milked at first extraction (day 0) and second extraction (day 7). G2: Scorpions milked at first extraction (day 0) and second extraction (days15). G3: Scorpions milked at first extraction (day 0 ) and second extraction (days 21). Separating gel 16\%, stacking gel $4 \%$. Molecular weight protein marker from $14.3 \mathrm{kDa}-67 \mathrm{kDa}$ was used

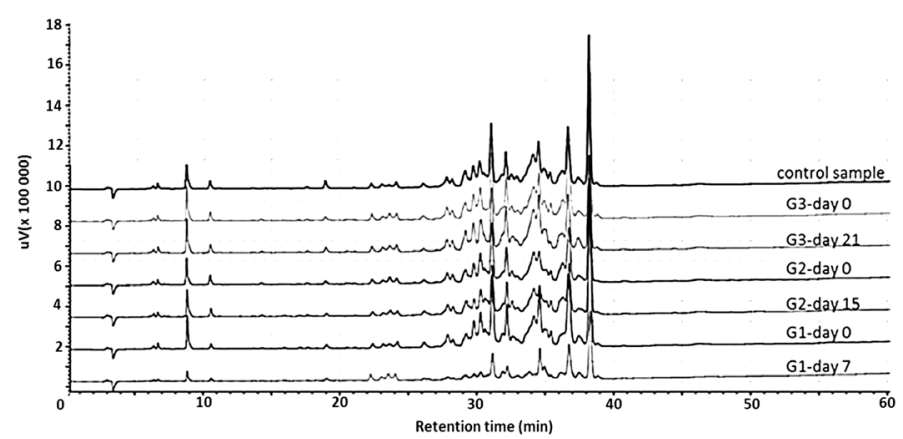

Figure 2. HPLC chromatographic profile of Rhopalurus junceus scorpion venom $(200 \mu \mathrm{g})$ from the three experimental groups after first and second extraction. G1: Scorpions milked at first extraction (day 0) and second extraction (day 7). G2: Scorpions milked at first extraction (day 0) and second extraction (day 15). G3: Scorpions milked at first extraction (day 0) and second extraction (day 21). Control sample: Scorpion venom obtained from additional group milked 30 days after previous extraction all groups, at first extraction, were similar between them and respect to control sample (Figure 2). The main differences in peak area between first and second extraction, was observed in G1 group (Table 2).

The peak areas between 5-29 min of retention time showed higher values at day 7 than first extraction (Table 2). The G2 group, at second extraction, showed a decreased in protein content compare to G1 group, at similar retention times (Table 2). Different from previous groups, the G3 group showed similar peak area values in both extractions. On other hands, peak areas from 30-40 min of retention time represent the highest proportion in all chromatograms. The peak areas between 30-40 min of retention time in G1 group, showed lower values at day 7 than previous extraction (Table 2). The G2 group, at second extraction, showed a slight recovery in protein content compare to G1 group, at similar retention times (Table 2). Meanwhile, G3 groups showed similar peak area values in first and second extraction.

The biological effect of scorpion venom from the different extractions periods was evaluated against human cancer cell line, A549, the insect cell line, C6/36HT and the monkey kidney cell line, Vero. The $\mathrm{IC}_{50}$ value was used to measure the effect of scorpion venom on cell viability of all three cell lines. In cancer cell line, in G1 group, the first extraction exerted a significant reduction of cell viability. The $\mathrm{IC}_{50}$ value in first extraction was significant different $(\mathrm{p}<0.01)$ respect to second extraction where no effect on cell viability was observed (Table 3 ). In G2 group, the $\mathrm{IC}_{50}$ value in first extraction was still significant lower $(\mathrm{p}<0.05)$ respect to second extraction where marginal cytotoxic effect was obtained (Table 3). Meanwhile, the G3 group showed similar $\mathrm{IC}_{50}$ values for both first and second extraction (Table 3).

Different from the effect on A549 cancer cells, the scorpion venom showed cytotoxic effect at each extraction period on $\mathrm{C6} / 36 \mathrm{HT}$ cell line (Table 3). The three groups showed a similar behavior considering the effect on $\mathrm{C} 6 / 36 \mathrm{HT}$ cell viability. The $\mathrm{IC}_{50}$ values were not significant different within each group and between groups (Table 3). In Vero cell line, the scorpion venom from each extraction period did not show cytotoxic effect in the range of concentration tested (Table 3 ).

\section{Discussion}

The scorpion venoms are now very popular natural extracts usually used for pharmacological investigations [13,14]. Due this, the parameters affecting the venom consistency should be analyzed. Among them, the study of frequency of venom collection is necessary to understand the process of venom regeneration in order to obtain reproducible results in pharmacological and toxicological experiments.

In our study, venom was obtained by electric stimulation. This method has been recognized to cause fewer traumas and best yields

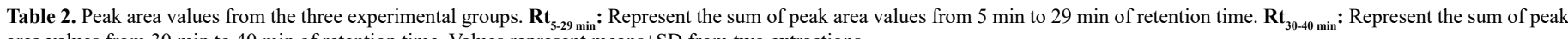
area values from $30 \mathrm{~min}$ to $40 \mathrm{~min}$ of retention time. Values represent means $\pm \mathrm{SD}$ from two extractions

\begin{tabular}{|c|c|c|c|c|c|c|c|}
\hline \multirow{2}{*}{\multicolumn{2}{|c|}{$\begin{array}{c}\text { Groups } \\
\text { Extraction day }\end{array}$}} & \multicolumn{2}{|c|}{ G1 } & \multicolumn{2}{|c|}{ G2 } & \multicolumn{2}{|c|}{ G3 } \\
\hline & & \multirow{2}{*}{$\begin{array}{c}\mathbf{0} \\
17.79 \pm 3.48\end{array}$} & \multirow{2}{*}{$\begin{array}{c}7 \\
23.84 \pm 1.42\end{array}$} & \multirow{2}{*}{$\begin{array}{c}\mathbf{0} \\
18.51 \pm 3.95\end{array}$} & \multirow{2}{*}{$\begin{array}{c}\mathbf{1 5} \\
19.12 \pm 2.96\end{array}$} & \multirow{2}{*}{$\begin{array}{c}\text { 0 } \\
18.53 \pm 3.96\end{array}$} & \multirow{2}{*}{$\begin{array}{c}\mathbf{2 1} \\
17.89 \pm 1.73\end{array}$} \\
\hline Peak area (o/) & $\mathbf{R t}_{5-29 \min }$ & & & & & & \\
\hline Peak area (\%) & $\mathbf{R t}_{30-40 \text { min }}$ & $81.49 \pm 4.73$ & $74.29 \pm 5.99$ & $80.17 \pm 3.32$ & $78.91 \pm 3.41$ & $79.62 \pm 5.45$ & $80.29 \pm 2.08$ \\
\hline
\end{tabular}

Table 3. $\mathrm{IC}_{50}$ values obtained after $R$. junceus scorpion venom treatment, at different concentrations against three cell lines. " $>1 "$ means No Effect. Values represent the mean $\pm \mathrm{SE}$ obtained from three independent experiments. G1: Scorpions milked on day 1 and 7. G2: Scorpions milked on day 1 and 15. G3: Scorpions milked on day 1 and 21. IC $\mathbf{5}_{50}$ : Venom concentration that causes $50 \%$ reduction of cell viability compared to untreated control cell. Asterisk (*) indicates a significant difference between extraction periods ( $\left(^{*} \mathrm{p}<0.05\right.$, $\left.{ }^{* *} \mathrm{p}<0.01\right)$ in the same group

\begin{tabular}{|c|c|c|c|c|c|c|c|}
\hline \multirow{2}{*}{\multicolumn{2}{|c|}{$\begin{array}{c}\text { Groups } \\
\text { Extraction day }\end{array}$}} & \multicolumn{2}{|c|}{ G1 } & \multicolumn{2}{|c|}{ G2 } & \multicolumn{2}{|c|}{ G3 } \\
\hline & & \multirow{2}{*}{$\begin{array}{c}\mathbf{0} \\
0,70 \pm 0,10^{* *}\end{array}$} & \multirow{2}{*}{$\begin{array}{c}7 \\
>1\end{array}$} & \multirow{2}{*}{$\frac{\text { 0 }}{0,73 \pm 0,35^{*}}$} & \multirow{2}{*}{$\begin{array}{c}\mathbf{1 5} \\
1,05 \pm 0,29\end{array}$} & \multirow{2}{*}{$\begin{array}{c}\mathbf{0} \\
0,67 \pm 0,23\end{array}$} & \multirow{2}{*}{$\begin{array}{c}\mathbf{2 1} \\
0,70 \pm 0,18\end{array}$} \\
\hline \multirow{3}{*}{$\mathrm{IC}_{50}(\mathrm{mg} / \mathrm{mL})$} & A549 & & & & & & \\
\hline & C6/36HT & $0,79 \pm 0,15$ & $0,61 \pm 0,09$ & $0,69 \pm 0,12$ & $0,78 \pm 0,13$ & $0,70 \pm 0,11$ & $0,65 \pm 0,10$ \\
\hline & Vero & $>1$ & $>1$ & $>1$ & $>1$ & $>1$ & $>1$ \\
\hline
\end{tabular}


can be obtained compared to other methods [7]. Manual extraction and maceration do not guarantee a complete extraction of venom components [9]. Additionally, these methods provoke the release of undesirable substance present in scorpion venom, which could interfere with the presence of the main components responsible for toxicological and immunological properties in scorpion venoms [7].

Frequency of venom collection arises as an important issue considering quantity and quality of venom, because in their natural environment, the scorpions, after stung, should be having a resting period to restore all venom components [4]. Some studies reveal that production and store of venom components in glands is a very expensive process involving an important increase in energetic and metabolic rate in earlier milked specimens to fulfill all venom components $[4,15]$. Analysis of histology and ultrastructure of venoms glands evidenced that there are different types of venom producing-cells which contain high amount of mitochondrias and granules with different sizes, types and densities [16,17]. Thus, suggesting that venom production is carried out sequentially and besides confirming that is very costly for scorpions as metabolic and energy-consuming process [16], arising the importance of establishing defined periods of venom collection.

Previous report evidenced that seventy two hours after scorpion milking, venom still do not completely recover and only a little part is regenerated [4]. Yaqoob and collaborators studied the conditions for maximum venom collection in different scorpion species. They found that Mesobuthus tamulus and Odontobuthus odonturus do not yield venom after 5-6 consecutive extractions with time lapse of 15 days [8]. In a similar study, the effect of consecutive extractions on venom quantity from two different scorpion species was analyzed [9]. The authors found that quantity of venom production decreased gradually after 7-8 consecutive extractions for both species, when a 15 days interval was used between extractions [9]. Our results agree with all these reports, where in general 15 day intervals was not enough to obtain full venom quality and quantity in scorpion venom.

In our study, considering the second extraction in each group, there is a positive correlation among the increase of time of venom milking, the increase of venom concentration and composition and the significant cytotoxic effect against cancer cells. This evidence suggests that active components affecting cancer cells are not produced in the initial stages of venom regeneration or reach their minimal proportion for significant cancer cell toxicity, only after the first three weeks of venom renewal. Similar to us, previous report with venom from the spider Cupiennius salei evidenced that newly regenerated venom had a low protein content and was correlated with less toxic symptoms when assayed in crickets [18].

Different from cancer cells, in normal cells, there were no evidences of cytotoxicity in none of the extraction periods evaluated which corroborate the absence of potential harmful to normal mammal tissue as was suggested previously for this scorpion venom $[5,6,19]$.

Interestingly, the scorpion venom exerts similar significant cytotoxic effect against $\mathrm{C} 6 / 36 \mathrm{HT}$ insect cells when compare the first and second extraction period in all three groups. This result suggests that venom components, mainly ion channels-modulating toxins, responsible for prey capture are produced from the beginning, after scorpion milking, as priority among all components. Thus, once venom is fully released from gland, scorpions must immediately regenerate components for capturing new preys, representing a necessary adaptive behavior in their natural environment [20]. Besides, these results agree with the fact that the highest proportion of components in the scorpion venoms correspond to peptide toxins that interact with ion channels present in insect cells, which represent the main diet in their natural ecosystems [21].

The elution times at 5-29 min and 30-40 min represent two defined chromatographic regions due, to in the first one usually appears $\mathrm{K}^{+}$channels-recognizing peptides and the second one, $\mathrm{Na}^{+}$-channelsrecognizing peptides, as was mentioned previously [22]. The analysis of second extractions reveal that when considering both chromatographic regions there were no correlated changes among milking intervals, respect to the percentage of total peaks area. Therefore, while venom components eluting at 5-29 min are potentially completed within 15 days, the remaining need longer times, suggesting that venom proteins regenerate asynchronously. There are similar reports for asynchronous venoms regeneration in scorpion [3,23], snakes [24,25], spiders [18] and centipedes [26] species, confirming the importance of determining frequency of venom collection for venomous animals.

Besides, HPLC analysis showed that second venom extraction at G1 group has a high proportion of components eluting between 5-29 min, respect to former extraction. As is shown in the chromatographic profiles, this proportion is occurring probably because the low molecular weight components eluting between 5-29 min require low metabolic rate and short time to be obtained by secretory cells during the process of venom regeneration. The later components eluting between 30-40 min seems to require high energy consume and longer time for renewal respect to earlier one. The components eluting first in HPLC usually include peptides that act on potassium channels with molecular weight under $4 \mathrm{kDa}$, non-disulfide bridge peptides (NDBP) corresponding generally with antimicrobial activities and other low molecular weight components [27]. Rodríguez-Ravelo and collaborators carried out a comparison of venom components between male and female $R$. junceus scorpion by using some proteomic approaches [28]. They isolated, identified and sequenced two peptide toxins, Rj1m1 and $\mathrm{Rj} 1 \mathrm{~m} 2$ with elution times of 23.36 and $23.59 \mathrm{~min}$ corresponding to $\mathrm{K}^{+}$-channel specific peptides [28]. Other proteomic analysis has shown that elution times below 30 min in HPLC column, trend to match with putative $\mathrm{K}^{+}$channels specific toxins [27].

Conversely, in the G1 group, in the second extraction, the components eluting between 30-40 min. of elusion time are in lesser proportion than first extraction. Here are mainly locate peptide components with greater structural complexity, Peptide components with greater structural complexity, are fundamentally $\mathrm{Na}^{+}$-channelsinteracting toxins and usually represent the highest proportion among all venom components [29]. In accordance with this results, GarcíaGomez and collaborators carried out the identification, isolation and sequencing of different peptide toxins from $R$. junceus venom using HPLC procedures similar to us. In all cases, the peptide toxins described, obtained from 30-34 min of retention times were identified as sodium channel-modulating toxins and in experiments with insects caused symptoms of intoxication in crickets related to loss of equilibrium, paralysis of rear limbs, some contracture of the body and death [21]. These evidences, together with the relevance of these peptide toxins for scorpion venoms [27], suggest that low proportion of components eluting between 30-40 min, in the second extraction from G1, should correspond to important sodium channel-modulating toxins capable of recognizing insect cells.

\section{Conclusion}

Our work provides for the first-time interesting data about the prominence of $R$. junceus venom regeneration for obtaining full venom 
composition, in order to guarantee reproducible result of biological activity against cancer cells. Besides, the study reveals evidences about the sequential regeneration of components responsible of biological activity against mammal and insect cells which represents a particular physiological behavior of $R$. junceus scorpion.

\section{Acknowledgments}

The authors are grateful to colleagues from Technical and scientific Support Department of Tropical Medicine Institute "Pedro Kouri" in their support to maintain cell culture. Besides, authors want to acknowledge particularly the assistance of the personnel from the scorpion Bioterium especially to personal of scorpion bioterium facilities LABIOFAM-Cienfuegos.

\section{Funding}

This research did not receive any specific grant from funding agencies in the public, commercial, or not-for-profit sectors.

\section{Conflict of interest}

None of the authors have any competing interest in the manuscript.

\section{Ethical approval}

The obtain, bioterium condition, management of scorpion colonies, and collection of venom have been approved by the Ministry of Science, Technology and Environment of Cuba (CITMA 20/2016).

\section{References}

1. Kalapothakis E, Chavez-Olortegui C (1997) Venom variability among several tityus serrulatus specimens. Toxicon 35: 1523-1529.

2. Pucca M, Amorim F, Cerni F, Bordon KdC, Cardoso I, et al. (2014) Influence of poststarvation extraction time and prey-specific diet in Tityus serrulatus scorpion venom composition and hyaluronidase activity. Toxicon 90: 326-336.

3. Nisani Z, Boskovic D, Dunbar S, Kelln W, Hayes WK (2012) Investigating the chemical profile of regenerated scorpion (Parabuthus transvaalicus) venom in relation to metabolic cost and toxicity. Toxicon 60: 315-323. [Crossref]

4. Nisani Z, Dunbar S, Hayes W (2007) Cost of venom regeneration in Parabuthus transvaalicus. Comp Biochem Physiol 147: 509-513.

5. Díaz-García A, Morier-Díaz L, Frión-Herrera Y, Rodríguez-Sánchez H, CaballeroLorenzo Y, et al. (2013) In vitro anticancer effect of venom from Cuban scorpion Rhopalurus junceus against a panel of human cancer cell lines. J Venom Res 12: 5-12.

6. Díaz-García A, Ruiz-Fuentes J, Rodríguez-Sánchez H, Fraga Castro J (2017) Rhopalurus junceus scorpion venom induces apoptosis in the triple negative human breast cancer cell line MDA-MB-231. J Venom Res 8: 9-13.

7. Oukkache N, Chgoury F, Lalaoui M, Alagón A, Ghalim N (2013) Comparison between two methods of scorpion venom milking in Morocco. J Venom Anim Toxins Incl Trop Dis 19.

8. Yaqoob R, Tahir H, Arshad M, Naseem S, Ahsan M (2016) Optimization of the conditions for maximum recovery of venom from scorpions by electrical stimulation. Pakistan J Zool 48: 265-269.

9. Tobassum S, Tahir HM, Zahid MT, Gardner QA, Ahsan MM (2018) Effect of Milking Method, Diet, and Temperature on Venom Production in Scorpions. J Insect Sci 18. [Crossref]

10. Herrera Y, Heras N, Cardoso D (1999) Adaptación a microplacas y validación de la técnica de Lowry. VacciMonitor 3: 7-11.
11. Díaz-García A, Ruiz-Fuentes J, Yglesias-Rivera A, Rodríguez-Sánchez H, Riquenes Garlobo Y, et al. (2015) Enzymatic analysis of venom from Cuban scorpion Rhopalurus junceus. J Venom Res 6: 11-18.

12. Mosmann T (1983) Rapid colorimetric assay for cellular grow and survival: application to proliferation and citotoxicity assays. J Immunol Meth 65: 55-63.

13. Ding J, Chua PJ, Bay BH, Gopalakrishnakone P (2014) Scorpion venoms as a potential source of novel cancer therapeutic compounds. Exp Biol Med 239: 387-393.

14. Rapôso C (2017) Scorpion and spider venoms in cancer treatment: state of the art challenges, and perspectives. J Clin Trans Res 3: In Press.

15. Mccue M (2006) Cost of producing venom in three North American pitviper species. Copeia 4: 818-825.

16. Yigit N, Benli M (2010) Fine structural analysis of the stinger in venom apparatus of the scorpion Euscorpius mingrelicus (Scorpiones: Euscorpiidae). J Venom Anim Toxins incl Trop Dis 16: 76-86.

17. Yigit N, Benli M(2008) The venom gland of the scorpion species Euscorpius mingrelicus (Scorpiones: Euscorpiidae) morphological and ultrastructural characterization. J Venom Anim Toxins incl Trop Dis 14: 466-480.

18. Boevé JL, Kuhn-Nentwig L, Keller S, Nentwig W (1995) Quantity and quality of venom released by a spider (Cupiennius salei, Ctenidae). Toxicon 33: 1347-1357.

19. García-Gómez B, Coronas F, Restano-Cassulini R, Rodríguez R, Possani L (2011) Biochemical and molecular characterization of the venom from the Cuban scorpion Rhopalurus junceus. Toxicon 58: 18-27.

20. van der Meijden A, Koch B, van der Valk T, Vargas-Muñoz L, Estrada-Gómez S (2017) Target-specificity in scorpions, comparing lethality of scorpion venoms across arthropods and vertebrates. Toxins 9: E312.

21. Polis G (1990) The biology of scorpions. Stanford university press, Stanford, California.

22. Batista C, D’Suze G, Gómez-Lagunas F, Zamudio F, Encarnación S, et al. (2006) Proteomic analysis of Tityus discrepans scorpion venom and amino acid sequence of novel toxins. Proteomics 12: 3718-3727.

23. Pimenta A, De Marco Almeida F, de Lima M, Martin-Eauclaire M, Bougis P (2003) Individual variability in Tityus serrulatus (Scorpiones, Buthidae) venom elicited by matrix-assisted laser desorption/ionization time-of-flight mass spectrometry. Rapid Commun Mass Spectrom 17: 413-418.

24. Guo Y, Liu H, Lin Y, Liang M (2009) Non-parallel expression of atriflavin-like disintegrin venom protein in the main glands of Trimeresurus mucrosquamatus. Toxin Rev 28: 266-270.

25. Luna M, Hortencio T, Ferreira Z, Yamanouye N (2009) Sympathetic out-flow activates the venom gland of the snake Bothrops jararaca by regulating the activation of transcription factors and the synthesis of venom gland proteins. J Exp Biol 212: 15351543.

26. Cooper A, Kelln W, Hayes W (2014) Venom regeneration in the centipede Scolopendra polymorpha:evidence for asynchronous venom component synthesis. Zool 117: 398414 .

27. Santibáñez-López C, Possani L (2015) Overview of the Knottin scorpion toxin-like peptides in scorpion venoms: Insights on their classification and evolution. Toxicon 107: 317-326.

28. Rodríguez-Ravelo R, Coronas F, Zamudio F, González-Morales L, López G, et al (2013) The Cuban scorpion Rhopalurus junceus (Scorpiones, Buthidae): component variations in venom samples collected in different geographical areas. J Venom Anim Toxins Incl Trop Dis 19.

29. Romero-Gutiérrez M, Santibáñez-López C, Jiménez-Vargas J, Batista C, Ortiz E, et al. (2018) Transcriptomic and proteomic analyses reveal the diversity of venom components from the vaejovid scorpion serradigitus gertschi. Toxins 10: E359.

Copyright: @2019 Díaz-García A. This is an open-access article distributed under the terms of the Creative Commons Attribution License, which permits unrestricted use, distribution, and reproduction in any medium, provided the original author and source are credited. 